\title{
SPATIOTEMPORAL VARIABILITY OF INDOOR ATMOSPHERIC EMISSIONS IN THE MEGA-CITY OF PAKISTAN
}

\author{
JAVED, H..$^{1 *}$ - GHANI, N. ${ }^{1}-$ GHANI, N. ${ }^{2}-$ TAHIR, A. ${ }^{1}$ - NASIR, A. H. ${ }^{3}-$ ZAHID, H. ${ }^{4,5}$ \\ ${ }^{I}$ Department of Environmental Science, Lahore College for Women University, \\ Lahore, Pakistan \\ ${ }^{2}$ Neurological Department, The Children's Hospital and The Institute of Child Health, \\ Lahore, Pakistan \\ ${ }^{3}$ Pak Green Enviro-Engineering, Lahore, Pakistan \\ ${ }^{4}$ EnviroSafe Consults, Lahore, Pakistan \\ ${ }^{5}$ HSE Culture Developers, Lahore, Pakistan \\ *Corresponding author \\ e-mail: houdajaved@yahoo.com; ORCID: 0000-0002-6758-0551 \\ (Received $7^{\text {th }}$ Dec 2018; accepted $28^{\text {th }}$ Jan 2019)
}

\begin{abstract}
Many sites of the world are currently faced with the prospects of air pollution. It is well established that photocopying machines generally contribute to the indoor emissions of Volatile Organic Compounds (VOCs) and Ozone that strongly influence the health of individuals. The current study aimed to discern the spatiotemporal variations of indoor Total Volatile Organic Compounds (TVOCs) and Ozone using a real-time monitoring approach in photocopying centers over mega-city of Pakistan. The real-time monitoring transcribed the diurnal variability of TVOCs and Ozone in photocopying centers $(n=200)$ during working hours (8:00 AM to 8:00 PM). Spatially, a high degree fluctuation was observed in the indoor level concentrations of TVOCs and Ozone. A typical diurnal cycle with a minimum value in the morning and a maximum in the noon with a gradual decrease until night was observed for TVOCs and Ozone suggesting that the photocopying emissions were a major source of generation. A significantly strong positive correlation was found between TVOCs and Ozone $(r=0.627, p<0.001)$. The findings were compared with the available standards indicating the potential of health hazards to workers.
\end{abstract}

Keywords: air pollution, ozone, photocopying machines, indoor environment, total volatile organic compounds

\section{Introduction}

In the current era of mechanization, photocopying machines are among the imperative accessories in the office setup. Globally, photocopying industry is a source of earning for millions of workers. A prominent modification with regards to the technical aspects, basic material, convenience, yield and skillfulness in the photocopying process has also encountered (Elango et al., 2013; Kasi et al., 2018).

In spite of commercial ease and viability, photocopiers are considerable initiators of air pollution. During functional mode, photocopiers release particles of toner, volatile and semi-volatile organic compounds, particulate matter, particles of paper, nanoparticles, ammonia, ozone, oxides of nitrogen, metals including arsenic, iron, chromium, titanium, zinc, nickel, cadmium, elemental sulphur and silicon (Durga Ch and Gokhale, 2015; Lee et al., 2006; Bar-Sela and Shoenfeld, 2008; Barthel et al., 2011; Bello et al., 2013; Wensing et al., 2008; Morawska et al., 2009; Adetunji et al., 2009; Pirela et al., 2013; Kleinsorge et al., 2011). 
The tracking of Volatile Organic Compounds is required to evaluate the air quality. Spatiotemporal fluctuation of VOCs with respect to source is crucial in alleviating photochemical pollution (Huang et al., 2014). The chemical deterioration of VOCs gives rise to secondary air pollutants including peroxyacetyl nitrate (PAN), secondary organic aerosols and aldehydes. Sunlight as an auxiliary component in the presence of nitrogen oxides and volatile organic compounds promotes the generation of ground level ozone. The profile of VOCs and ozone reveals that the generation of ozone is VOC restricted (Srivastava et al., 2005; Lee et al., 2002; Toro et al., 2006). The association between the atmospheric emissions in terms of Nitrogen oxides and VOCs couples with the generation of ozone (Xu et al., 2017).

Ozone is a predominant component of the atmosphere that is of crucial importance to global climatic variation and tropospheric chemistry (Reddy et al., 2012). The precursors and elevated ozone levels are of great concern owing to the deleterious effects on the human health, forests, plants, natural and anthropogenic materials (Mavroidis and Ilia, 2012; Fann and Risley, 2013; Szyszkowicz et al., 2012; Kheirbek et al., 2013; Kumar et al., 2014a, b; Singh et al., 2014).

The traditional methods for the detection of organic compounds can require weeks to systematize, execute, delineate and interpret results. Direct reading methods (DRMs) have been initiated in workplaces as a substitutive approach with the benefits of swift measurement of the concentration (Brown et al., 2016). Direct reading methods using a portable real-time monitor for the detection of VOCs is a convenient tool (Coy et al., 2000; Peng et al., 2007). For the measurement of Volatile Organic Compounds at workplace, commercially available PID has been used for several decades (Driscoll, 2013).

Various kinds of compact portable VOC monitors are available nowadays. A monitor employing photoionization detector (PID) is able to detect Total Volatile Organic Compounds (TVOCs) with the intervening time of few seconds. The sensitivity of the measurement was outlined to range from ppb to ppm (RAE Systems, 2005). The PIDsupported VOC monitor is anticipated to be a beneficial tool for the accurate measurement of TVOC exposure (Mizukoshi et al., 2010). As a segment of an effort in comprehending the role of photocopying process in the generation of TVOC and Ozone, the current study aims to perform real-time monitoring of TVOC and Ozone in photocopying centers and to evaluate the temporal and spatial variation in different areas of Lahore, Pakistan.

\section{Materials and methods}

\section{Sampling area}

Lahore is a megacity of Pakistan with the inhabitants of about $10+$ million people (Razi et al., 2017). It is situated between $30.25^{\circ} \mathrm{N}$ to $31.5^{\circ} \mathrm{N}$ and $73^{\circ} \mathrm{E}$ to $74.5^{\circ} \mathrm{E}$ and a provincial capital of Punjab covering an area of 1, $172 \mathrm{~km}^{2}$ (ul-Haq et al., 2016). Lahore is characterized by the semi-arid climatic conditions with very hot and wet summer and ordinarily cool and dry winter. In the month of June, the recorded highest maximum temperature was $48^{\circ} \mathrm{C}$; whereas, the lowest temperature was recorded to be $-2^{\circ} \mathrm{C}$ in January. Lahore is documented with an annual rainfall of $489 \mathrm{~mm}$ (Ali et al., 2014). The photocopying centers $(n=200)$ in the vicinity of Lahore were selected randomly. For the convenience, the sampling areas were divided into two different zones. The 
sampling areas of the current study are outlined in Figure 1. For the collection of baseline data of photocopying centers, a self-structured questionnaire was designed.

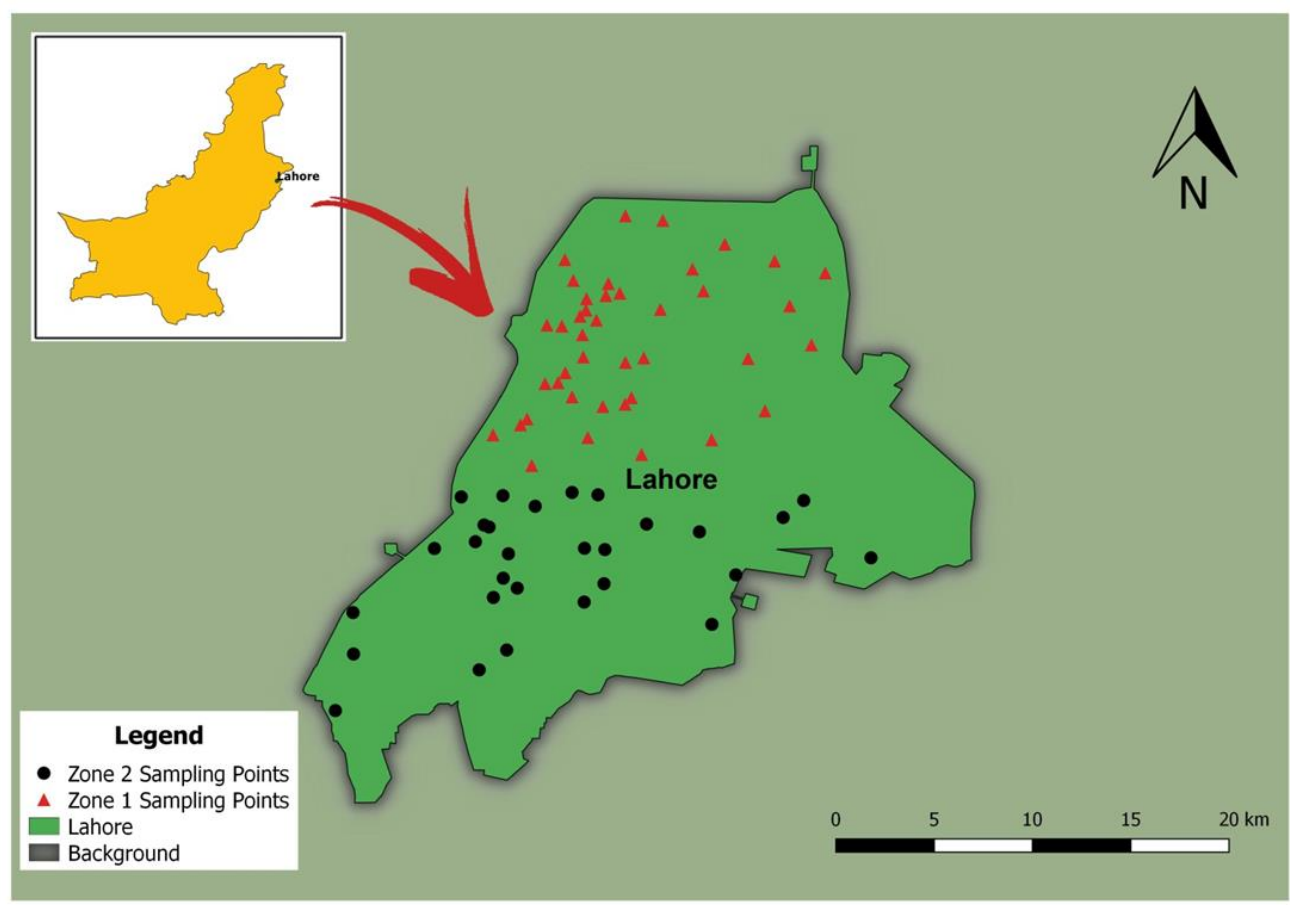

Figure 1. Sampling areas of Lahore, Pakistan

\section{Monitoring instruments and technique}

Monitoring was performed for the Total Volatile Organic Compounds (TVOCs) and Ozone $\left(\mathrm{O}_{3}\right)$ during the working hours in photocopying centers. A hand-held digital realtime VOC monitor with PID detector [ToxiRAE Pro PID (RAE Systems by Honeywell, 4.6" H X 2.4" W X 1.2" D, $235 \mathrm{~g})$ ] was employed as shown in Figure $2 a$. The monitor was characterized by the photoionization sensor with $10.6 \mathrm{eV}$ lamp. The response time of the VOC monitor was $<15 \mathrm{~s}$. The monitor was turned on and the self-testing was performed by the instrument. Following the normal start-up process, the main measurement screen was displayed. The instrument specified the readings in parts per million (ppm). The documented values were converted to isobutylene equivalent concentrations in $\mathrm{mg} / \mathrm{m}^{3}$. Since Isobutylene is conventionally used for the calibration of PID detectors (RAE Systems, 2005).

For the monitoring of Ozone, portable single gas detector [BW Technologies GAXTG-DL Gas Alert Ozone (1.1"X 2.0" X 3.75", 82 g, by BW Technologies)] was employed with the concentration range of $0-1.00 \mathrm{ppm}$ as shown in Figure $2 b$. The response time of Ozone monitor was $5 \mathrm{~s}$. The self-testing was executed by the detector after being turned on. The normal start-up screen was displayed. The readings of Ozone were converted to $\mu \mathrm{g} / \mathrm{m}^{3}$. The TVOC and Ozone monitors can measure the concentrations every second. For the average concentration of TVOC and Ozone in an hour, the average concentration of 10-min interval derived from original 1-min interval reading was utilized. The TVOC and Ozone measuring instruments were placed inside the photocopying centers at the height of approximately 1.1-1.5 $\mathrm{m}$ above the ground 
(Meciarova et al., 2017). Meanwhile, it was ensured that the instruments are away from the direct pollutant sources and ventilation openings (Moreno-Rangel et al., 2018).

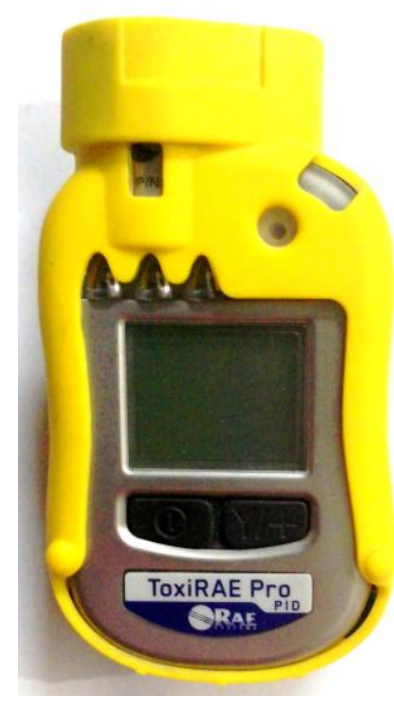

a

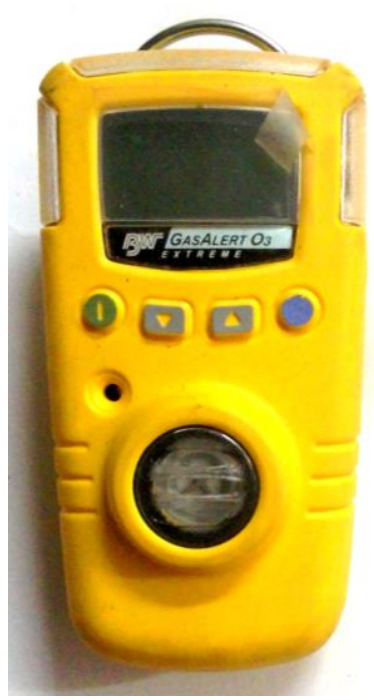

b

Figure 2. Monitoring instrument for $\boldsymbol{a}$ TVOC and $\boldsymbol{b}$ Ozone

\section{Data analysis}

The mean TVOC and Ozone concentrations at a particular sampling point were shown in the maps. In order to analyze the spatial variability of TVOC and Ozone, the local interpolation method i.e., Inverse Distance Weighting (IDW) was employed using the QGIS Desktop 2.18.12.

Statistical analyses were executed by using SPSS [IBM SPSS Statistics Version 20 for Windows, SPSS Inc., Chicago, IL, USA]. The normal distribution of the data was determined by using Shapiro-Wilk Test. For categorical variables, Chi-square test was executed. For the data with no normal distribution, Mann Whitney $U$ test was employed. Spearman's Rank correlation test was performed to quantify the correlation between testing variables. The Friedman Test was applied for assessing the difference in the concentrations of TVOC and Ozone with time of the day. The p-value $<0.05$ was considered to be significant.

\section{Results and discussion}

The baseline attributes from photocopying centers were documented using a selfstructured questionnaire as presented in Table 1. No significant difference was observed in terms of average working hours, number of machines and nature of area in photocopying centers located in both zones.

\section{Spatial variability of total volatile organic compounds and ozone}

The spatial variations of Total Volatile Organic Compounds (TVOCs) in $\mathrm{mg} / \mathrm{m}^{3}$ and Ozone in $\mu \mathrm{g} / \mathrm{m}^{3}$ are presented in Figures $3 a, b$ and $4 a, b$. A high degree fluctuation was observed in the concentrations of both variables. 
Table 1. Baseline attributes of photocopying centers

\begin{tabular}{|c|c|c|c|c|}
\hline & Total $(n=200)$ & Zone $1(\mathrm{n}=92)$ & Zone $2(n=108)$ & p-value \\
\hline Average working hours & $11.97 \pm 0.47$ & $12.02 \pm 0.55$ & $11.93 \pm 0.38$ & $0.194 *$ \\
\hline No. of workers & $2.30 \pm 1.80$ & $2.21 \pm 2.25$ & $2.38 \pm 1.31$ & $0.027 *$ \\
\hline $\begin{array}{c}\text { No. of machines in the } \\
\text { working centers }\end{array}$ & $2.90 \pm 1.52$ & $2.72 \pm 1.61$ & $3.05 \pm 1.44$ & $0.063 *$ \\
\hline $\begin{array}{c}\text { No. of black and white } \\
\text { machines }\end{array}$ & $2.63 \pm 1.24$ & $2.47 \pm 1.29$ & $2.76 \pm 1.183$ & $0.052 *$ \\
\hline No. of colored machines & $0.29 \pm 0.58$ & $0.25 \pm 0.59$ & $0.31 \pm 0.57$ & $0.206 *$ \\
\hline $\begin{array}{l}\text { No. of machines in working } \\
\text { condition }\end{array}$ & $2.73 \pm 1.57$ & $2.59 \pm 1.62$ & $2.84 \pm 1.52$ & $0.144 *$ \\
\hline $\begin{array}{c}\text { No. of machines not in } \\
\text { working condition }\end{array}$ & $0.19 \pm 0.50$ & $0.13 \pm 0.40$ & $0.25 \pm 0.57$ & $0.093 *$ \\
\hline Presence of computer & $\begin{array}{c}\text { Yes }=189(94.5 \%) \\
\text { No }=11(5.5 \%)\end{array}$ & $\begin{array}{l}\text { Yes }=82(89.1 \%) \\
\text { No }=10(10.9 \%)\end{array}$ & $\begin{array}{c}\text { Yes }=107(99.1 \%) \\
\text { No }=1(0.9 \%)\end{array}$ & $0.002 * *$ \\
\hline Nature of area & $\begin{array}{c}\text { Well ventilated = } \\
30(15 \%) \\
\text { Ventilated }=55 \\
(27.5 \%) \\
\text { Congested = } 68 \\
(34 \%) \\
\text { Dark and congested } \\
=34(17 \%) \\
\text { Dark and very } \\
\text { congested = } 13 \\
(6.5 \%)\end{array}$ & \begin{tabular}{|} 
Well ventilated = \\
$14(15.2 \%)$ \\
Ventilated $=22$ \\
$(23.9 \%)$ \\
Congested = 30 \\
$(32.6 \%)$ \\
Dark and congested \\
$=21(22.8 \%)$ \\
Dark and very \\
congested = 5 \\
$(5.4 \%)$ \\
\end{tabular} & $\begin{array}{c}\text { Well ventilated = } 16 \\
(14.8 \%) \\
\text { Ventilated }=33 \\
(30.6 \%) \\
\text { Congested = 38 } \\
(35.2 \%) \\
\text { Dark and congested } \\
=13(12 \%) \\
\text { Dark and very } \\
\text { congested = } 8 \\
(7.4 \%)\end{array}$ & $0.331 * *$ \\
\hline Air conditioner & $\begin{array}{c}\text { Yes }=12(6 \%) \\
\text { No }=188(94 \%) \\
\end{array}$ & $\begin{array}{c}\text { Yes }=9(9.8 \%) \\
\text { No }=83(90.2 \%)\end{array}$ & $\begin{array}{c}\text { Yes }=3(2.8 \%) \\
\text { No }=105(97.2 \%)\end{array}$ & $0.038 * *$ \\
\hline $\begin{array}{l}\text { Average No. of copies per } \\
\text { day }\end{array}$ & $2860.63 \pm 5601.65$ & $2280.71 \pm 6650.59$ & $3354.63 \pm 4495.12$ & $0.000 *$ \\
\hline
\end{tabular}

*Mann Whitney U test, **Chi square test

\section{Diurnal variability of total volatile organic compounds}

The diurnal variation of Total Volatile Organic Compounds (TVOC) in $\mathrm{mg} / \mathrm{m}^{3}$ is presented in Figure 5. The average TVOC $\left(\mathrm{mg} / \mathrm{m}^{3}\right)$ during working hours in photocopying center of Zone 1 and Zone 2 was found to be $0.674 \pm 0.699$ and $0.691 \pm$ 0.786 , respectively. The average TVOC concentration in photocopying centers located in Zone 1 was marginally lower than the centers in Zone 2. However, regarding the concentration of TVOCs, no significant difference was observed in the photocopying centers located in two different zones. In Zone 1, the diurnal variation revealed a similar pattern throughout the day with the lowest value observed at 8:00 am in the morning when the photocopying centers were opened. In case of Zone 2, the highest value of TVOC was observed at 12 Noon. Thereafter, it decreases gradually with the lower value during closing time of the photocopying centers. Several studies reported the generation of Volatile Organic Compounds in the photocopying centers (Stefaniak et al., 2000; Lu et al., 2015; Kowalska et al., 2015). A minimum TVOC concentration was observed during morning that gradually started increasing till noon. A progressive decline was found with the passage of time with the lower value at 8:00 pm. 


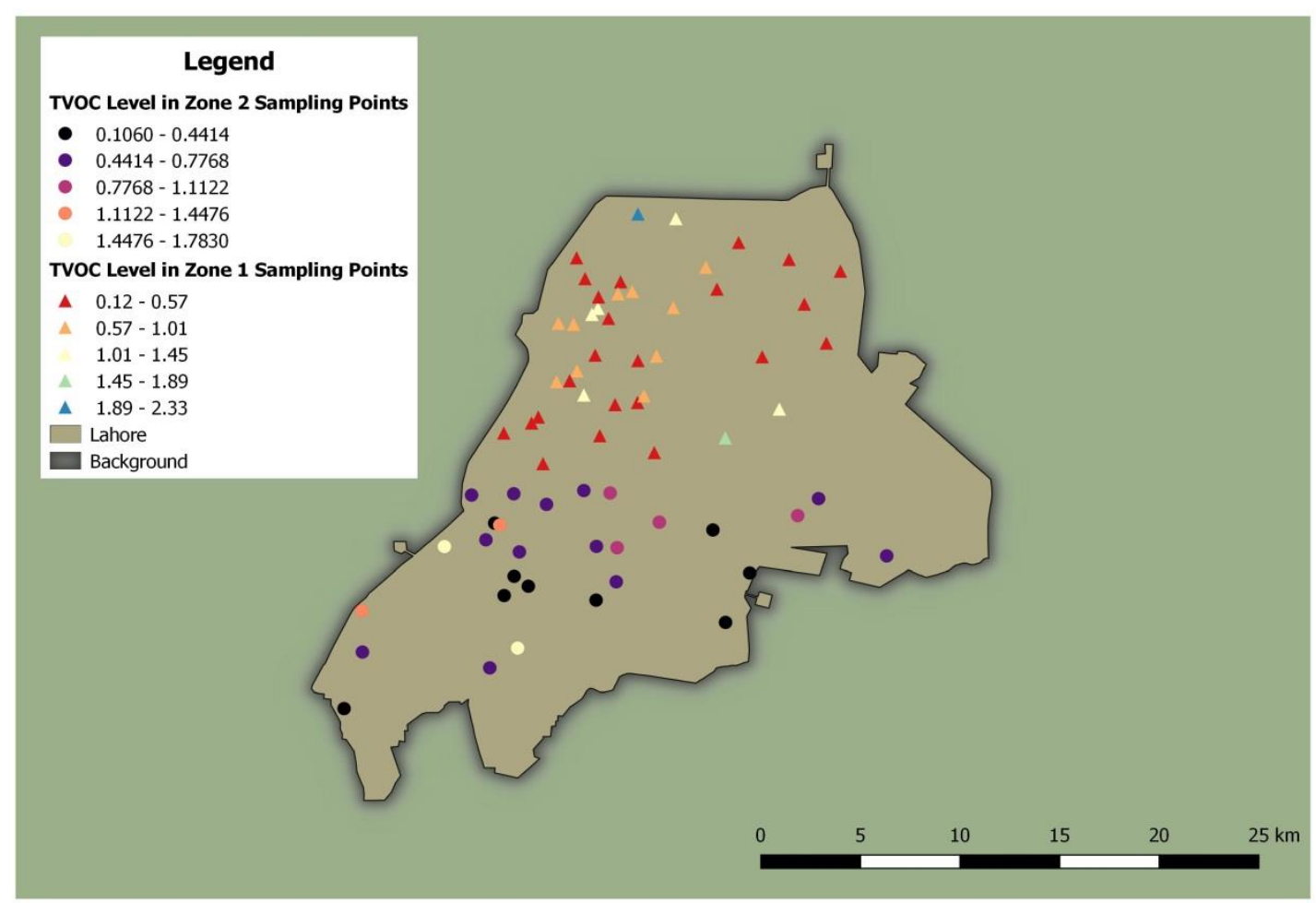

a

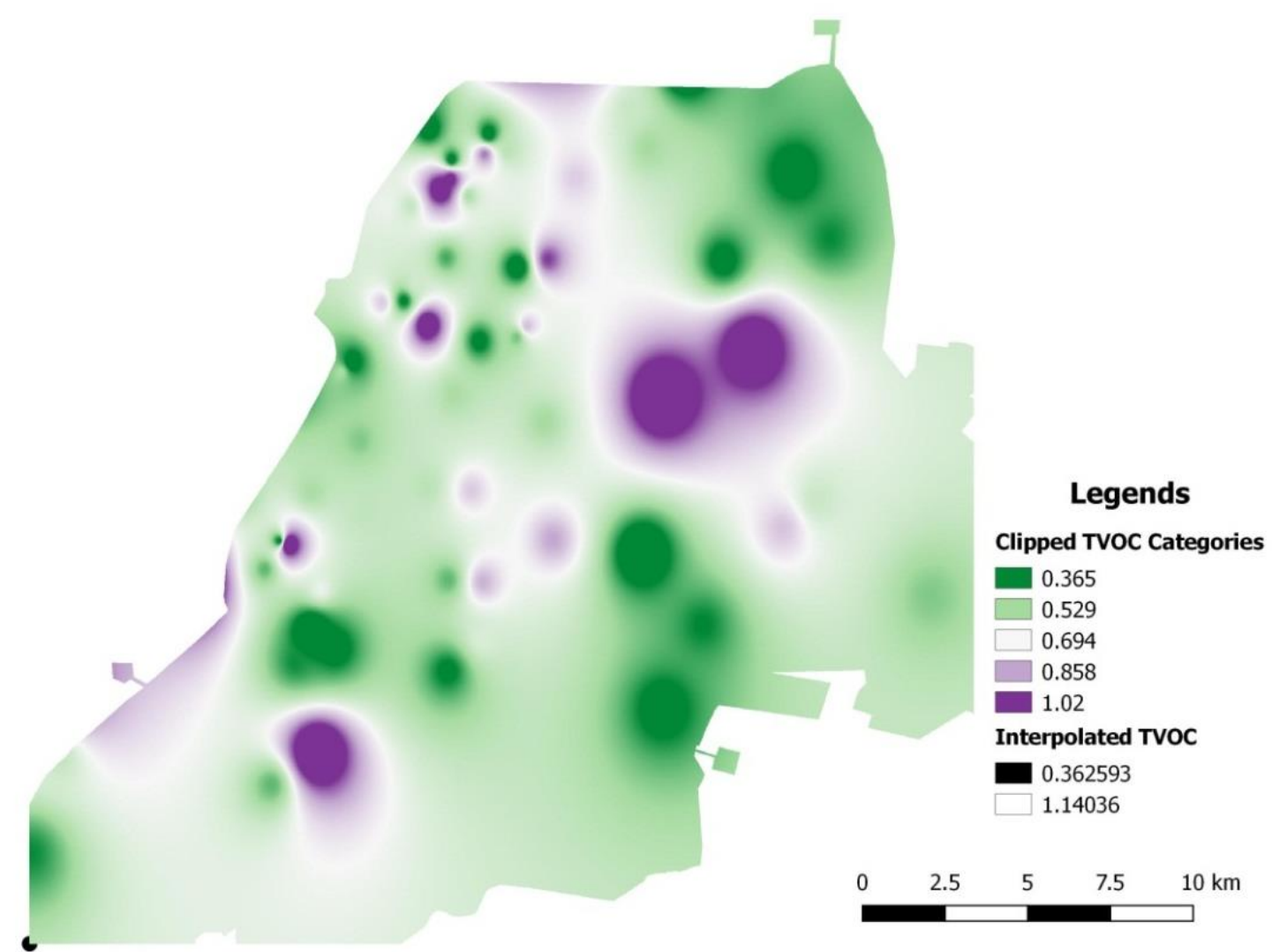

b

Figure 3. a Spatial distribution of mean TVOC concentrations in photocopying centers of Lahore. $\boldsymbol{b}$ Spatial distribution of TVOC concentrations by IDW method 


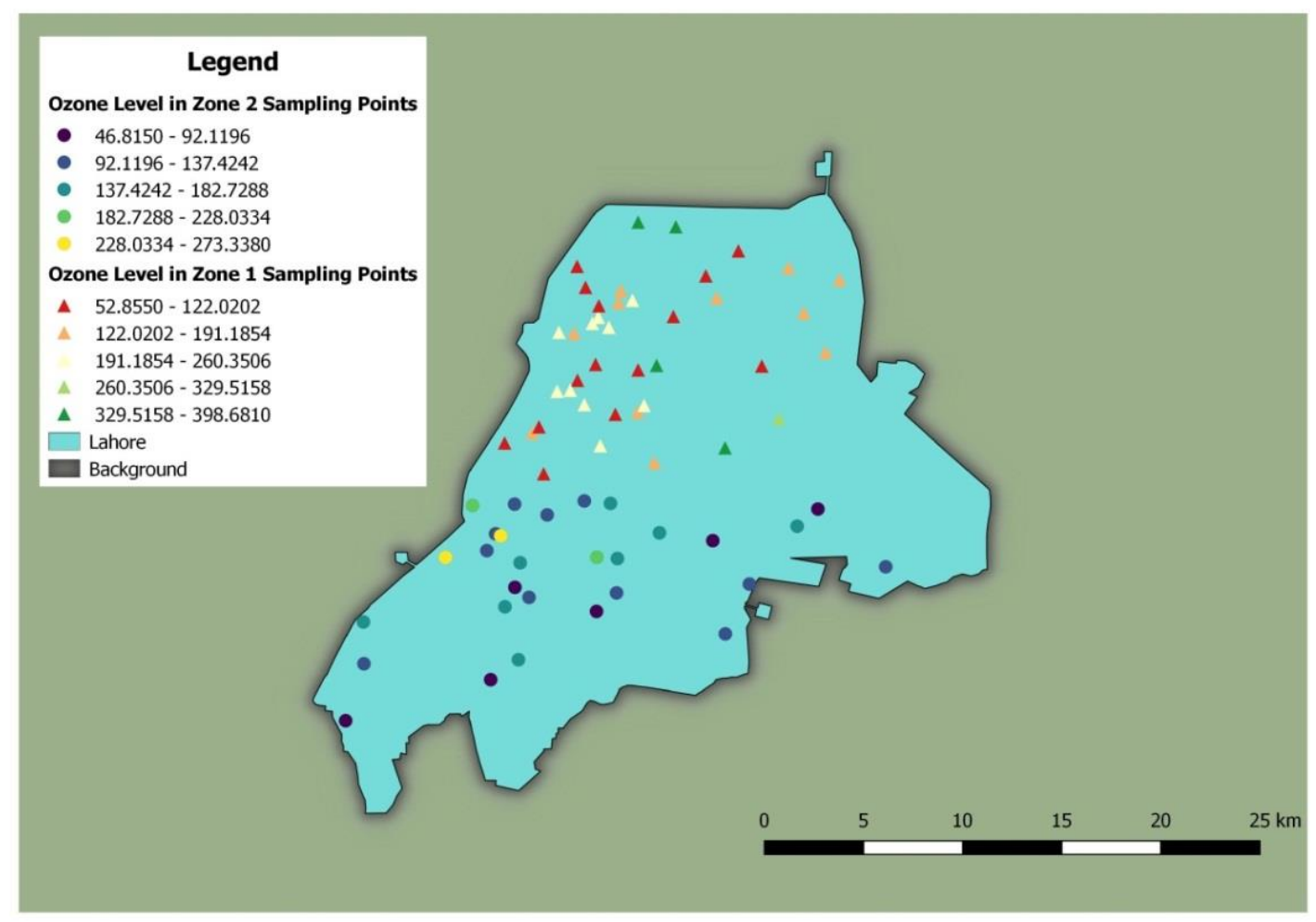

a

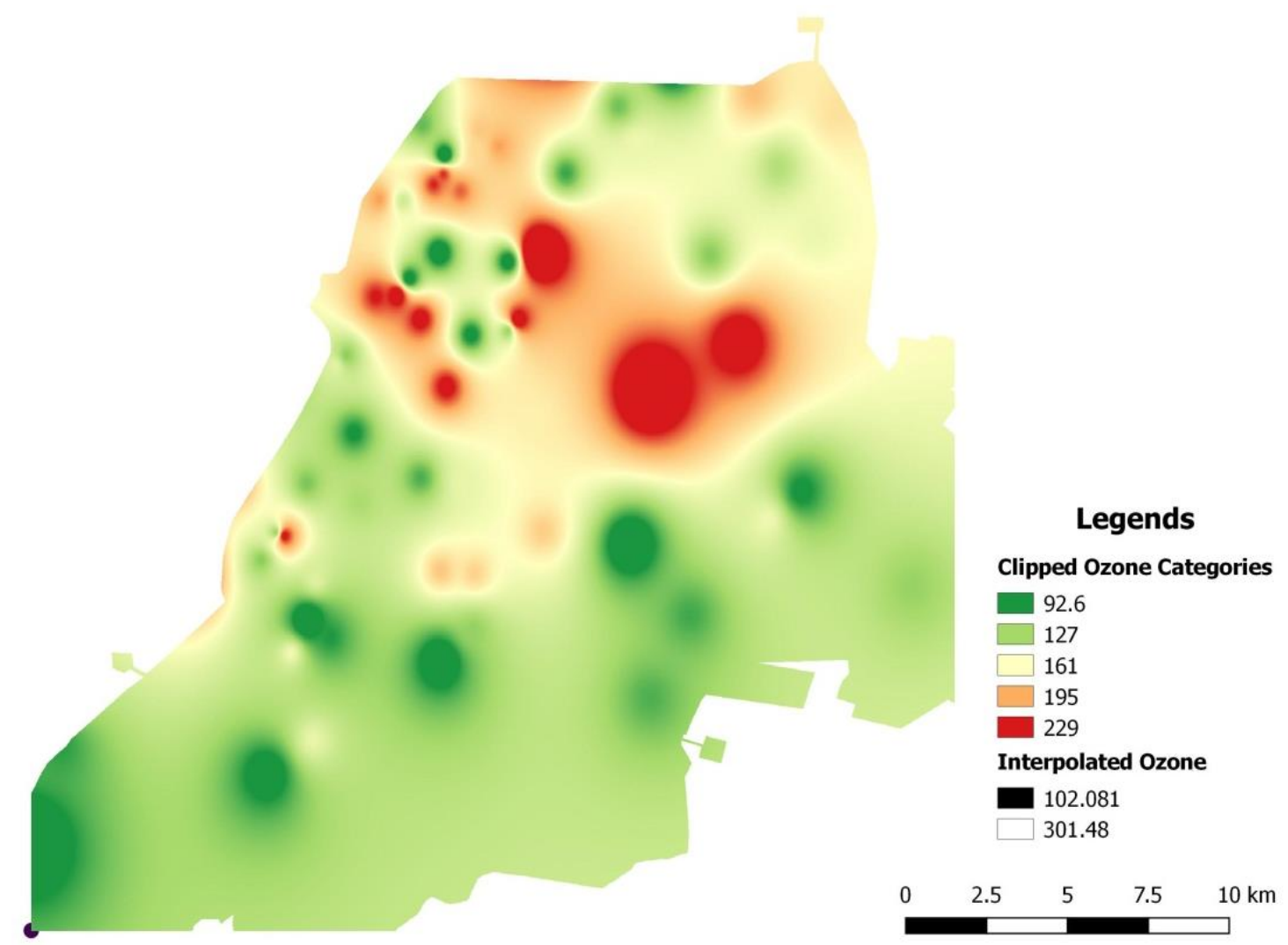

b

Figure 4. a Spatial distribution of mean Ozone concentrations in photocopying centers of Lahore. $\boldsymbol{b}$ Spatial distribution of Ozone concentrations by IDW method 


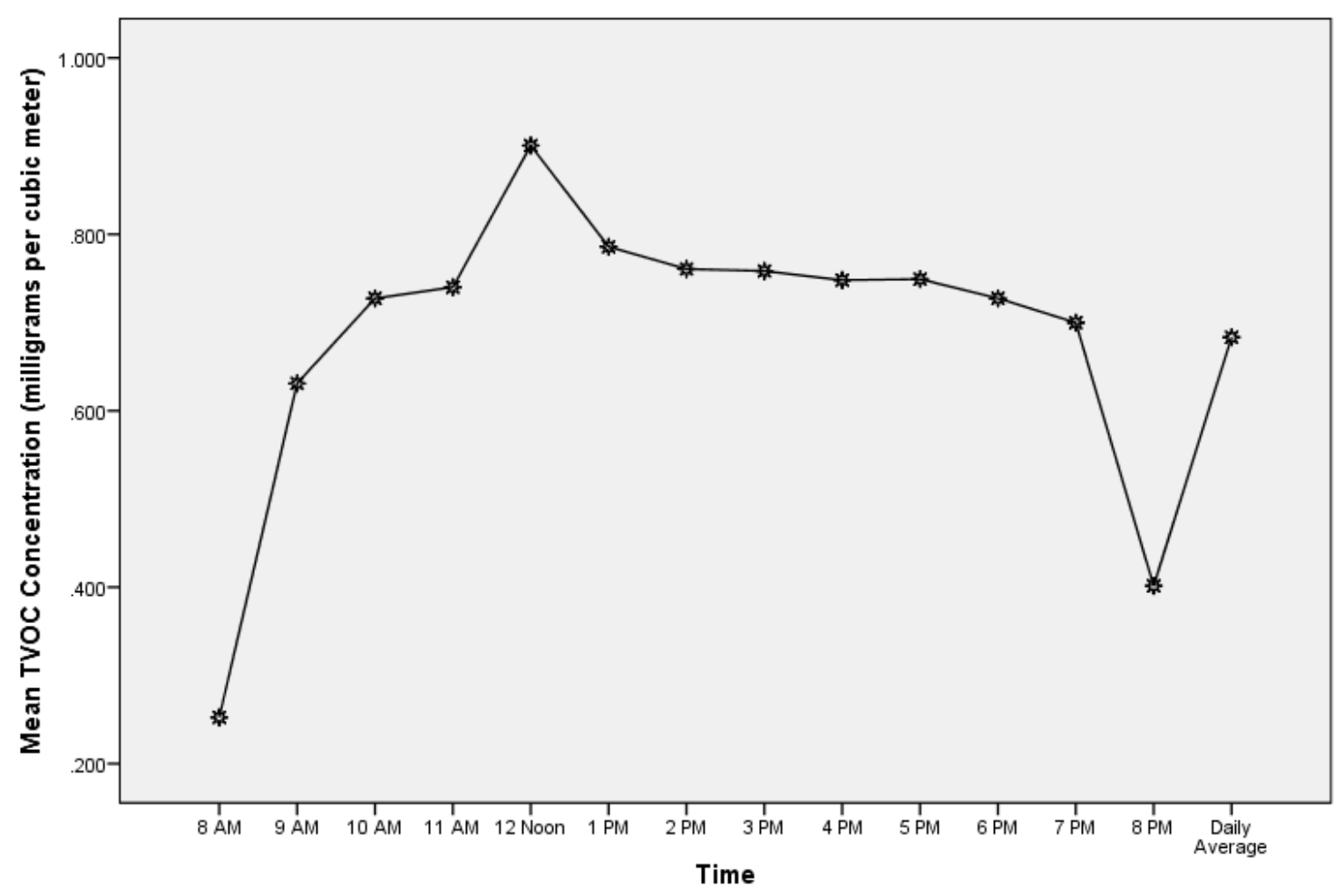

Figure 5. Diurnal pattern of TVOC $\left(\mathrm{mg} / \mathrm{m}^{3}\right)$ in photocopying centers

\section{Diurnal variability of Ozone}

The observed diurnal variability of Ozone at different photocopying centers is shown in Figure 6. The average concentration of Ozone $\left(\mu \mathrm{g} / \mathrm{m}^{3}\right)$ in Zone 1 and Zone 2 was found to be $187.50 \pm 119.28$ and $139.08 \pm 83.56$ respectively with the significant difference $(\mathrm{p}<0.05)$ between both the zones. A relatively steep slope was recorded for the concentration of ozone. The diurnal variation of Ozone revealed that the minimum concentration was observed at 8:00 in the morning. It indicates that the maximum concentration was observed at 12 noon. Thereafter, it gradually declines and reaches the minimum value during the night. The similar diurnal variability was documented in other studies (Xue et al., 2017; Adame Carnero et al., 2010; Kumar et al., 2014b).

The Spearman's correlation was determined to evaluate the association between the TVOC and Ozone concentration (Fig. 7). A positive and highly significant correlation exists between the concentrations $(\mathrm{r}=0.627, \mathrm{p}=0.000)$. The ozone precursors including oxides of nitrogen (NOx) and Volatile Organic Compounds (VOCs) vigorously affect the ozone profile (Filella and Penuelas, 2006).

In order to verify whether the time of the day makes any significant impact on the concentrations of TVOC and Ozone in photocopying centers, the Friedman test was employed. The significant results for both the concentrations indicated that the time of the day did have a significant impact on the concentrations of TVOC $\left(\chi^{2}=599.311\right.$, Df $=13$, Asym. Sig 0.000) and Ozone $\left(\chi^{2}=1357.799\right.$, Df $=13$, Asym. Sig 0.000). 


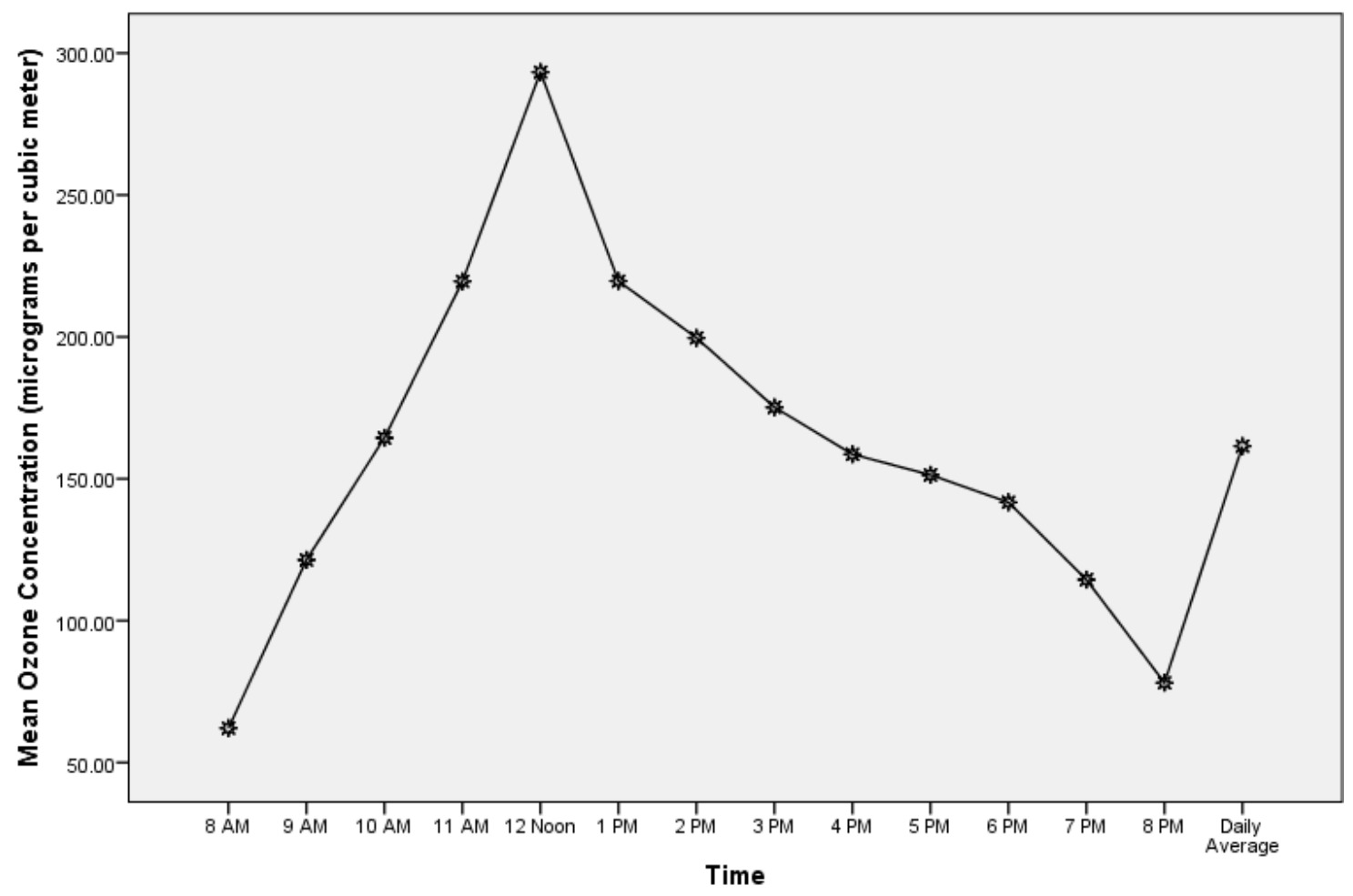

Figure 6. Diurnal pattern of Ozone $\left(\mu \mathrm{g} / \mathrm{m}^{3}\right)$ in photocopying centers

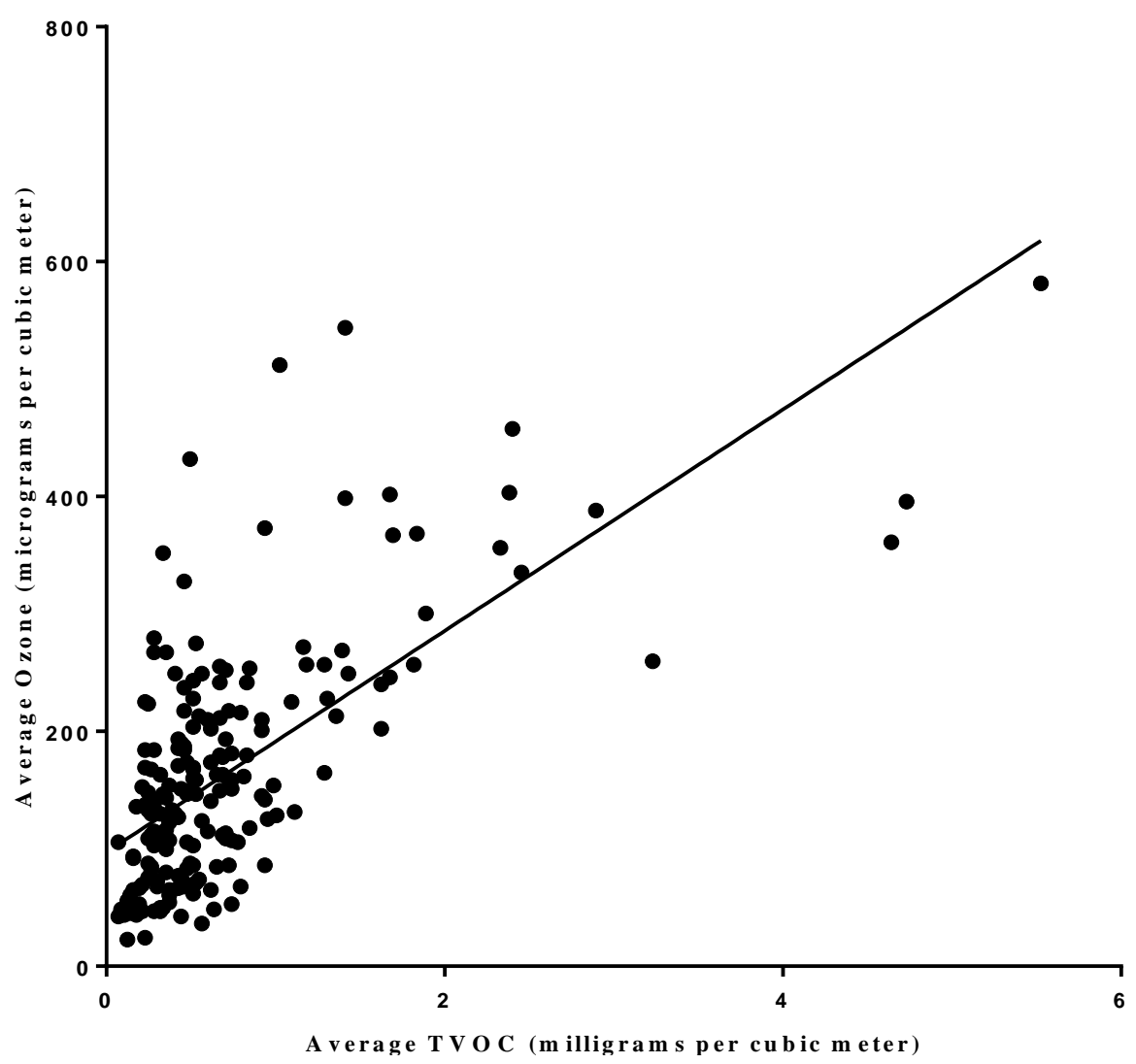

Figure 7. Correlation between average TVOC $\left(\mathrm{mg} / \mathrm{m}^{3}\right)$ and Ozone $\left(\mu \mathrm{g} / \mathrm{m}^{3}\right)$ 
The average number of copies made in each photocopying center per day was found to be positively correlated with the concentrations of TVOC and Ozone. A highly significant and positive association was found between the average number of copies per day and the concentration of TVOC $(r=0.556, p=0.000)$. Likewise, the average number of copies per day was computed to be positively and significantly correlated with the Ozone concentrations $(r=0.333, p=0.000)$.

\section{Concentration of TVOC and Ozone with respect to nature of area}

In order to compute the association between the concentration of the testing variable and the nature of the area, Kruskal-Wallis test was employed. Based on the observation, the nature of the area was divided into 5 main categories i.e., Well Ventilated, Ventilated, Congested, Dark and Congested, Dark and very Congested. A highly significant association $(\mathrm{p}<0.01)$ was observed between the nature of area and the concentrations of TVOC and Ozone (Figs. 8 and 9).

The observations of the current study revealed the variation in TVOC concentration at photocopying centers with respect to the nature of area. The maximum concentrations of TVOCs and ozone were observed in dark and very congested photocopying centers representing the significant role of ventilation in the declined TVOC concentration. Hori et al. (2013) reported the reduced concentration of TVOCs with the elevated ventilation.

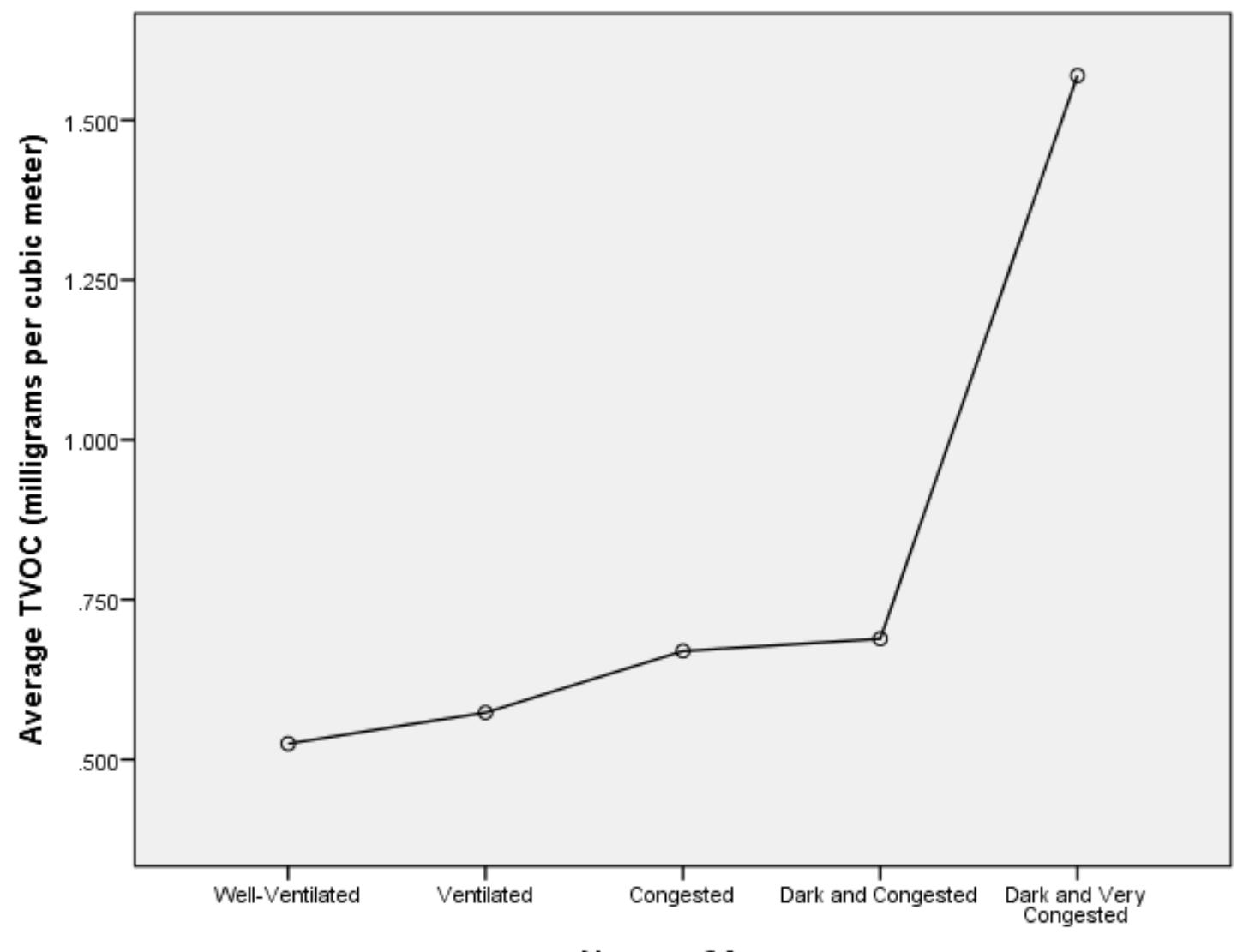

Nature of Area

Figure 8. Association between the nature of area and average TVOC $\left(\mathrm{mg} / \mathrm{m}^{3}\right)$ 


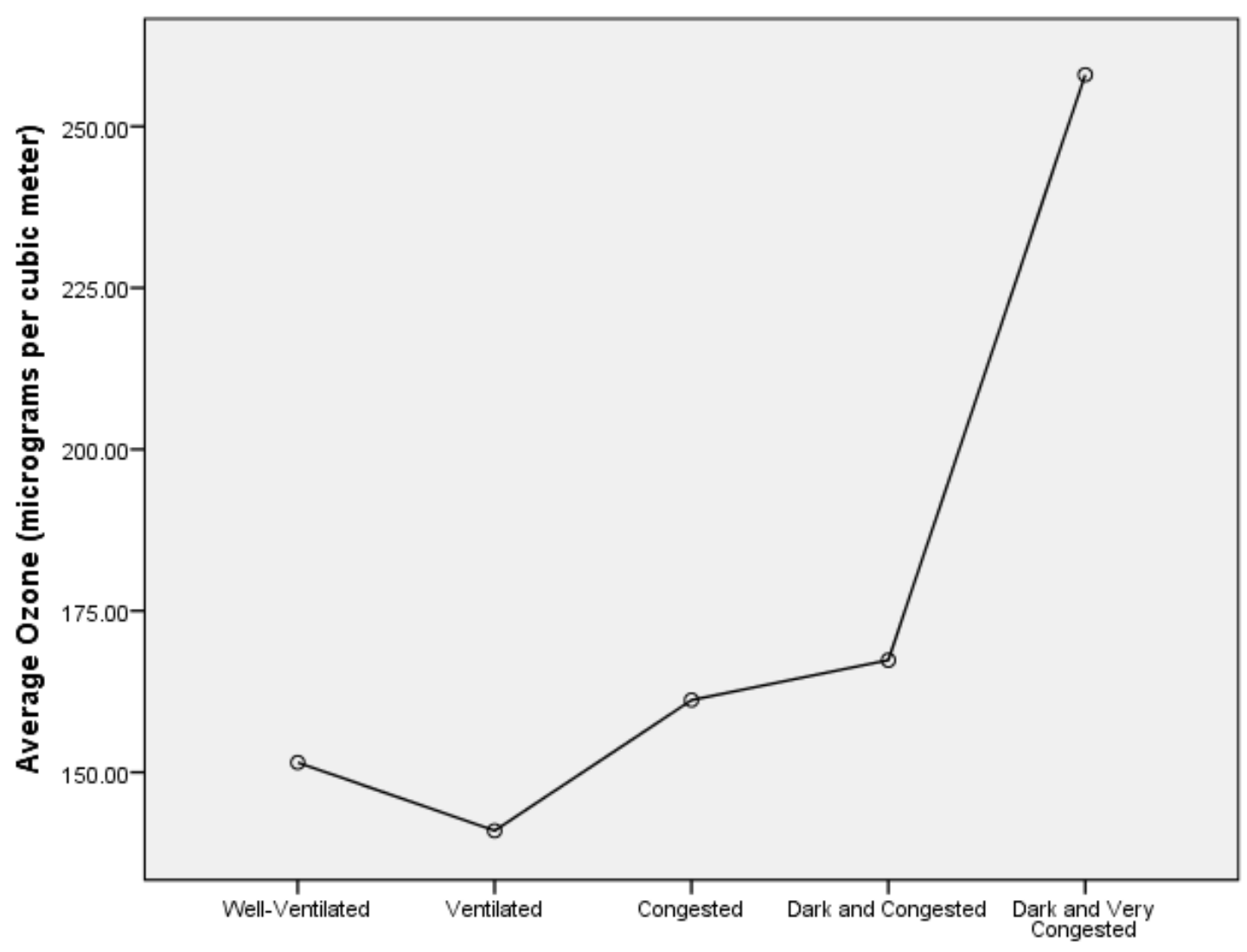

Nature of Area

Figure 9. Association between the nature of area and average Ozone $\left(\mu \mathrm{g} / \mathrm{m}^{3}\right)$

The concentration of ozone and its precursors may have a significant effect on the health of human beings (Kumar et al., 2014b). Keeping this in view, the results were compared with the available standards. In non-industrial indoor environment, discomfort and irritability ranges are defined by Molhave (1991). The concentration of VOCs below about $0.2 \mathrm{mg} / \mathrm{m}^{3}$ is considered to be the comfort range. Between $0.2-$ $3.0 \mathrm{mg} / \mathrm{m}^{3}$, Irritation and discomfort is possible if other exposures are encountered. The results of the current study with reference to the concentration of TVOCs indicate that it lies within the range of multifactorial exposures i.e. $0.2-3.0 \mathrm{mg} / \mathrm{m}^{3}$. As specified by the National Environmental Quality Standards for Ambient Air by Pak- EPA, the one hour average allowable concentration is $130 \mu \mathrm{g} / \mathrm{m}^{3}$. However, in the current study, the average concentration exceeded this allowable limit that may result in ill-health of the workers.

\section{Conclusion}

In this research, the spatial and temporal variations of the total volatile organic compounds and ozone concentrations measured at photocopying centers in Lahore are presented. The variations in the concentrations of TVOC and Ozone between sampling sites indicated the role of photocopying emissions in generating indoor air pollution. The daily cycle presents variations with respect to the time of the day. The maximum 
concentrations of TVOC and Ozone was observed at 12:00 Noon. The daily minimum concentration was monitored at 8:00 am and 8:00 pm with fluctuating values throughout the day. The findings from this research highlight the importance of monitoring strategy to ultimately develop effective control measures. The present research can be used to find the association with the health impacts in the workers. Furthermore, it is recommended to perform comprehensive research using an appropriate risk assessment strategy.

Acknowledgements. The authors are thankful to the Chairperson, Department of Environmental Science for administrative support during the study and staff of lab of the department. Meanwhile, the authors are thankful to Pak-Green Enviro-Engineering for the provision of instruments to conduct this research.

Conflict of interests. There is no conflict of interests among the authors about the research work.

Research funding. This research did not receive any specific grant from funding agencies in the public, commercial, or not-for-profit sectors.

\section{REFERENCES}

[1] Adame Carnero, J. A., Bolivar, J. P., de la Morena, B. A. (2010): Surface ozone measurements in the southwest of the Iberian Peninsula (Huelva, Spain). - Environmental Science and Pollution Research 17(2): 355-368.

[2] Adetunji, H., Pinto, L. M. M., Siddique, A., Samuel, S. (2009): Potential occupational health risk from exposure to nanoscale particles from photocopiers - a pilot study. Revue Internationale sur l'ingenierie des risques industriels 2(1): 15-27.

[3] Ali, M., Tariq, S., Mahmood, K., Daud, A., Batool, A., Zia-ul-Haq (2014): A Study of aerosol properties over Lahore (Pakistan) by using AERONET data. - Asia-Pacific Journal of Atmospheric Sciences 50(2): 153-162.

[4] Bar-Sela, S., Shoenfeld, Y. (2008): Photocopy machines and occupational antiphospholipid syndrome. - The Israel Medical Association Journal 10(1): 52-54.

[5] Barthel, M., Pedan, V., Hahn, O., Rothhardt, M., Bresch, H., Jann, O., Seeger, S. (2011): XRF-analysis of fine and ultrafine particles emitted from laser printing devices. Environmental Science \& Technology 45(18): 7819-7825.

[6] Bello, D., Martin, J., Santeufemio, C., Sun, Q., Lee Bunker, K., Shafer, M., Demokritou, P. (2013): Physicochemical and morphological characterisation of nanoparticles from photocopiers: implications for environmental health. - Nanotoxicology 7(5): 989-1003.

[7] Brown, K. K., Shaw, P. B., Mead, K. R., Kovein, R. J., Voorhees, R. T., Brandes, A. R. (2016): Development of the chemical exposure monitor with indoor positioning (CEMWIP) for workplace VOC surveys. - Journal of Occupational and Environmental Hygiene 13(6): 401-412.

[8] Coy, J. D., Bigelow, P. L., Buchan, R. M., Tessari, J. D., Parnell, J. O. (2000): Field evaluation of a portable photoionization detector for assessing exposure to solvent mixtures. - AIHAJ - American Industrial Hygiene Association 61(2): 268-274.

[9] Driscoll, J. N. (2013): Photoionization. - In: Smith, P. A., Cook, G. W. (ed.) Important Instrumentation and Methods for the Detection of Chemicals in the Field. American Industrial Hygiene Association, Falls Church, VA, pp. 39-54.

[10] Durga C., S., Gokhale, S. (2015): Monitoring and assessment of O3 and PM1 in the microenvironment of a workplace. - Environmental Modeling \& Assessment 20(5): 521534.

[11] Elango, N., Kasi, V., Vembhu, B., Poornima, J. G. (2013): Chronic exposure to emissions from photocopiers in copy shops causes oxidative stress and systematic inflammation among photocopier operators in India. - Environmental Health 12(1): 78. 
[12] Fann, N., Risley, D. (2013): The public health context for PM2.5 and ozone air quality trends. - Air Quality Atmosphere \& Health 6(1): 1-11.

[13] Filella, I., Peńuelas, J. (2006): Daily, weekly and seasonal relationships among VOCs, NOx and $\mathrm{O} 3$ in a semi-urban are near Barcelona. - Journal of Atmospheric Chemistry 54(2): 189-201.

[14] Hori, H., Ishimatsu, S., Fueta, Y., Ishidao, T. (2013): Evaluation of a real-time method for monitoring volatile organic compounds in indoor air in a Japanese University. Environmental Health and Preventive Medicine 18(4): 285-292.

[15] Huang, R. J., Zhang, Y., Bozzetti, C., Ho, K. F., Cao, J. J., Han, Y., Daellenbach, K. R., Slowik, J. G., Platt, S. M., Canonaco, F., Zotter, P., Wolf, R., Pieber, S. M., Bruns, E. A., Crippa, M., Ciarelli, G., Piazzalunga, A., Schwikowski, M., Abbaszade, G., SchnelleKreis, J., Zimmermann, R., An, Z., Szidat, S., Baltensperger, U., Haddad, I. E., Prévôt, A. S. H. (2014): High secondary aerosol contribution to particulate pollution during haze events in China. - Nature 514(7521): 218-222.

[16] Kasi, V., Elango, N., Ananth, S., Vembhu, B., Poornima, J. G. (2018): Occupational exposure to photocopiers and their toners cause genotoxicity. - Human \& Experimental Toxicology 37(2): 205-217.

[17] Kheirbek, I., Wheeler, K., Walters, S., Kass, D., Matte, T. (2013): PM2.5 and ozone health impacts and disparities in New York City: sensitivity to spatial and temporal resolution. - Air Quality Atmosphere \& Health, 6(2): 473-486.

[18] Kleinsorge, E. C., Erben, M., Galan, M. G., Barison, C., Gonsebatt, M. E., Simoniello, M. F. (2011): Assessment of oxidative status and genotoxicity in photocopier operators: a pilot study. - Biomarkers 16(8): 642-648.

[19] Kowalska, J., Szewczyńska, M., Pośniak, M. (2015): Measurements of chlorinated volatile organic compounds emitted from office printers and photocopiers. Environmental Science and Pollution Research International 22(7): 5241-5252.

[20] Kumar, A., Singh, B. P., Punia, M., Singh, D., Kumar, K., Jain, V. K. (2014a): Assessment of indoor air concentrations of VOCs and their associated health risks in the library of Jawaharlal Nehru University, New Delhi. - Environmental Science and Pollution Research International 21(3): 2240-2248.

[21] Kumar, A., Singh, B. P., Punia, M., Singh, D., Kumar, K., Jain, V. K. (2014b): Determination of volatile organic compounds and associated health risk assessment in residential homes and hostels within an academic institute, New Delhi. - Indoor Air 24(5): 474-483.

[22] Lee, C. W., Dai, Y. T., Chien, C. H., Hsu, D. J. (2006): Characteristics and health impacts of volatile organic compounds in photocopy centers. - Environmental Research 100(2): 139-149.

[23] Lee, S. C., Chiu, M. Y., Ho, K. F., Zou, S. C., Wang, X. (2002): Volatile organic compounds (VOCs) in urban atmosphere of Hong Kong. - Chemosphere 48(3): 375-382.

[24] Lu, C. Y., Lin, J. M., Chen, Y. Y., Chen, Y. C. (2015): Building-related symptoms among office employees associated with indoor carbondioxide and total volatile organic compounds. - International Journal of Environmental Research and Public Health 12(6): 5833-5845.

[25] Mavroidis, I., Ilia, M. (2012): Trends of NOx, NO2 and O3 concentrations at three different types of air quality monitoring stations in Athens, Greece. - Atmospheric Environment 63: 135-147.

[26] Meciarova, L., Vilcekova, S., Burdova, E. K., Kiselak, J. (2017): Factors affecting the Total Volatile Organic Compound (TVOC) concentrations in Slovak Households. International Journal of Environmental Research and Public Health 14(12): 1443.

[27] Mizukoshi, A., Kumagai, K., Yamamoto, N., Noguchi, M., Yoshiuchi, K., Kumano, H., Yanagisawa, Y. (2010): A novel methodology to evaluate health impacts caused by VOC exposure using real time VOC and Holter monitors. - International Journal of Environmental Research and Public Health 7(12): 4127-4138. 
[28] Mølhave, L. (1991): Volatile organic compounds, indoor air quality and health. - Indoor Air 1(4): 357-376.

[29] Morawska, L., He, C., Johnson, G., Jayaratne, R., Salthammer, T., Wang, H., Uhde, E., Bostrom, T., Modini, R., Ayoko, G., McGarry, P., Wensing, M. (2009): An investigation into the characteristics and formation mechanisms of particles originating from the operation of laser printers. - Environmental Science \& Technology 43(4): 1015-1022.

[30] Moreno-Rangel, A., Sharpe, T., Musau, F., McGill, G. (2018): Field evaluation of a lowcost indoor air quality monitor to quantify exposure to pollutants in residential environments. - Journal of Sensors and Sensor Systems 7: 373-388.

[31] Peng, F. M., Xie, P. H., Shi, Y. G., Wang, J. D., Liu, W. Q., Li, H. Y. (2007): Photoionization detector for portable rapid GC. - Chromatographia 65(5-6): 331-336.

[32] Pirela, S., Molina, R., Watson, C., Cohen, J. M., Bello, D., Demokritou, P., Brain, J. (2013): Effects of copy center particles on the lungs: a toxicological characterization using a Balb/c mouse model. - Inhalation Toxicology 25(9): 498-508.

[33] RAE Systems (2005): Application \& Technical Notes. 3rd Ed. - RAE Systems, San Jose, CA.

[34] Razi, M., Shaiganfar, R., Ahmad, N., Dorner, S., Khokhar, M. F., Beirle, S., Wagner, T. (2017): Estimation of NOx emissions from the Megacity of Lahore, Pakistan using car MAX-DOAS observations and comparison with OMI satellite data. - Geophysical Research Abstracts, 19 ${ }^{\text {th }}$ EGU General Assembly, EGU 2017, Proceedings from the Conference, Vienna, Austria, 23-28 April.

[35] Reddy, B. S. K., Kumar, K. R., Balakrishnaiah, G., Gopal, K. R., Reddy, R. R., Sivakumar, V., Lingaswami, A. P., Arafath, S. Md., Umadevi, K., Kumari, S. P., Ahammed, Y. N., Lal, S. (2012): Analysis of diurnal and seasonal behavior of surface ozone and its precursors (NOx) at a semi-arid rural site in Southern India. - Aerosol and Air Quality Research 12: 1081-1094.

[36] Singh, B. P., Kumar, A., Singh, D., Punia, M., Kumar, K., Jain, V. K. (2014): An assessment of ozone levels, UV radiation and their occupational health hazard estimation during photocopying operation. - Journal of Hazardous Materials 275: 55-62.

[37] Srivastava, A., Joseph, E., More, A., Patil, S. (2005): Emissions of VOCs at urban petrol retail distribution centres in India (Delhi and Mumbai). - Environmental Monitoring and Assessment 109(1-3): 227-242.

[38] Stefaniak, A. B., Breysse, P. N., Murray, M. P. M., Rooney, B. C., Schaefer, J. (2000): An evaluation of employee exposure to volatile organic compounds in three photocopy centers. - Environmental Research 83(2): 162-173.

[39] Szyszkowicz, M., Porada, E., Searles, G., Rowe, B. H. (2012): Ambient ozone and emergency department visits for skin conditions. - Air Quality Atmosphere and Health 5(3): 303-309.

[40] Toro, M. V., Cremades, L. V., Calbo, J. (2006): Relationship between VOC and NOx emissions and chemical production of tropospheric ozone in the Aburra Valley (Colombia). - Chemosphere 65(5): 881-888.

[41] Ul-Haq, Z., Tariq, S., Ali, M., Mahmood, K., Rana, A. D. (2016): Sulphur dioxide loadings over megacity Lahore (Pakistan) and adjoining region of Indo-Gangetic Basin. International Journal of Remote Sensing 37(13): 3021-3041.

[42] Wensing, M., Schripp, T., Uhde, E., Salthammer, T. (2008): Ultra-fine particles release from hardcopy devices: sources, real-room measurements and efficiency of filter accessories. - Science of the Total Environment 407(1): 418-427.

[43] Xu, Z., Huang, X., Nie, W., Chi, X., Xu, Z., Zheng, L., Sun, P., Ding, A. (2017): Influence of synoptic condition and holiday effects on VOCs and ozone production in the Yangtze River Delta region, China. - Atmospheric Environment 168: 112-124.

[44] Xue, Y., Ho, S. S. H., Huang, Y., Li, B., Wang, L., Dai, W., Cao, J., Lee, S. (2017): Source apportionment of VOCs and their impacts on surface ozone in an industry city of Boji, Northwestern China. - Scientific Reports 7(1): 9979. 